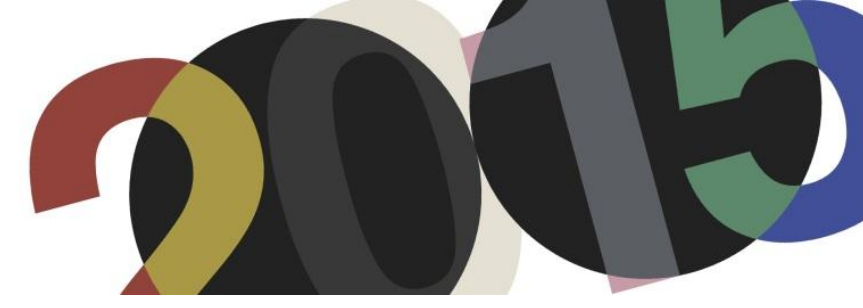

DOI: http://dx.doi.org/10.4995/LC2015.2015.926

\title{
Le Corbusier's Secret Geometry: Speculations on Regulating Lines Hidden in Ronchamp
}

\author{
P. Wood \\ Victoria University of Wellington, New Zealand
}

\begin{abstract}
Despite the prominence of Ronchamp in the work of Le Corbusier we remain largely ignorant of the geometric approach the architect applied to determine the specific relationship of the building's plan to its liturgical responsibilities. It is assumed that the Modulor was the principle proportional system used to determine the chapels plan. In this paper it is contented that the Modulor played a minor role in finding the principle geometric relationships, at least in plan. With reference to two formal explorations, the research presents two findings. Firstly, that in exploring primary relationships Le Corbusier was more likely to have made geometric reference to attributes of the extant site. A second part of this argument goes on to show that once the plan of Ronchamp was established it was used to provide geometric coordinates for other parts of the site development.
\end{abstract}

Resumen: A pesar de la prominencia de Ronchamp, en la obra de Le Corbusier que permanecen gran parte ignorante del enfoque geométrico el arquitecto aplicó para determinar la relación específica del plan del edificio para sus responsabilidades litúrgicas. Se supone que el Modulor fue el sistema proporcional principio utilizado para determinar el plan capillas. En este trabajo se está contento de que el Modulor jugó un papel de menor importancia en la búsqueda de las relaciones geométricas principales, por lo menos en el plan. Con referencia a las dos exploraciones formales, la investigación presenta dos conclusiones. En primer lugar, que en la exploración de las relaciones primarias Le Corbusier era más probable que hayan hecho referencia geométrica a los atributos del sitio existente. Una segunda parte de este argumento pasa a mostrar que una vez que se estableció el plan de Ronchamp se utiliza para proporcionar coordenadas geométricas de otras partes del desarrollo del sitio

Keywords: Ronchamp; geometry; proportion.

Palabras clave: Ronchamp; la geometría; proporción.

\section{Introduction}

Ronchamp is rightfully regarded as a masterpiece in Le Corbusier's oeuvre, and as such it has attracted continual attention from historians, critics and architects alike. It has been pointed out that archival information on Ronchamp is remarkable for the coverage it offers on his methodological design approach. ${ }^{1}$ And yet we remain largely ignorant of the geometric strategies Le Corbusier utilised to determine the specific relationship of the building's plan to its liturgical responsibilities. Indeed, many interpretations of Ronchamp tend to position it as an organic sculptural work somewhat apart from his other buildings ${ }^{2}$. It may well be that we prefer the image of Ronchamp as an act of pure creative expression. However romantic views are difficult to sustain if we consider the role the Modulor played in organising a plan so wilful in rejecting Cartesian coordination. That the Modulor underlies the complexity of Ronchamp is not in doubt. Corbusier went so far as to challenge visitors to discover it, calling it a game of proportions. In his petit monograph on Ronchamp Le Corbusier describes the Modulor as

\footnotetext{
${ }^{1}$ Pauly, D. (1985). "The Chapel of Ronchamp." Architectural Design 55(7/8): 30-37.

${ }^{2}$ See Jencks, C. (1987). Le Corbusier and the Tragic View of Architecture. Middlesex, England, Penguin Books.
} 
being 'everywhere', but he then writes: "I defy a visitor to give, offhand, the dimensions of the different parts of the building" ${ }^{3}$. In a similar vein elsewhere in this marvellous small book, Le Corbusier emphasis 'play' where he writes on the play of proportions, and the play of relationships. ${ }^{4}$ A third example of how Le Corbusier conceptualised Ronchamp as a geometric conundrum can be found in this rather melodramatic paragraph from The Modulor II:

"It was a pleasure, here, to allow free play to the resources of the Modulor, keeping a corner of one's eye on the game to avoid blunders, for blunders lie in wait for you, beckon you on, tug at your sleeve, drag you down into the abyss. $" 5$

In each of these descriptions Le Corbusier offers Ronchamp a kind of enigmatic game, a puzzle to be understood, if not solved. But it is not at all obvious who this riddle serves. Whether there is in Ronchamp a genuine intellectual challenge to those who experience the building, or if the building served a more internal creative dialogue for Le Corbusier's development of Modulor geometries?

\section{Methodological Approach}

In particular it is in the extraordinary plan of Ronchamp that we can observe a contestable territory between agreed accounts of the project's genesis (the disciplinary account) and diverse expositions on the chapel's symbolic iconography (Le Corbusier's personal narrative). Critiques of the plan have tended to operate on the assumption that the Modulor was a grand proportional determinant without ever testing this claim consistently or in detail. In a revealing passage in Modulor II Le Corbusier writes, in advance of Ronchamp's completion, that 'all will be coherent' and 'released by free invention' based on the 'faultless mathematics of the combinations'. But other than the proportional detailing of the flagstone floor the plan of Ronchamp defies simple explanation. Finding the Modulor in the chapel plans requires an act of faith in Le Corbusier's assertions that it is, indeed, integral, and in that moment it is demanded of us that we trust without evidence. As Robin Evans has put it, while it is difficult to see how the Modulor and Ronchamp are connected, it is easier to see how they are alike. ${ }^{6}$ Or perhaps we should say 'if we want to see how them as alike' as the issue here might be one of recognition rather than realisation?

In this paper I will be attempting to explain some part of Le Corbusier's Ronchamp riddle. Immediately this work is then defined by problems of translation as formal 'meaning' is retrieved from a language of building. This is fraught but it is in no way new to Corbusier scholarship. Ivan Zaknic has observed that literary translators of Le Corbusier have sometimes taken minute liberties with his words with significant consequences. ${ }^{7}$ But in the discipline of architecture translation is not limited to the written text. As Robin Evans continues elsewhere, translation is an instrumentation that underpins our entire disciplinary authority as architectural ideas move

\footnotetext{
${ }^{3}$ Le Corbusier (1957). The Chapel of Ronchamp. London, Architectural Press. Page 118.

${ }^{4}$ Le Corbusier (1957). The Chapel of Ronchamp. London, Architectural Press. Page 27.

${ }^{5}$ Le Corbusier (1958). Modulor 21955 (Let the User Speak Next) Continuation of 'The Modulor' 1948. Cambridge, Massachusetts, and London England, The M.I.T. Press. Page 254.

${ }^{6}$ Evans, R. (1995). The Projective Cast. Cambridge, Mass., The MIT Press. Page 279.

${ }^{7}$ The best example of this was when Frederick Etchells inserted the word 'new' into the title of Vers une architecture. Le Corbusier (1995). The Final Testament of Pere Corbu: A Translation and Interpretation of Mise au point by Ivan Zaknic. New Haven and London, Yale University Press. Page ix.
} 
between fields of representation, presentation and realisation. ${ }^{8}$ For Evans, Ronchamp offered a particularly acute problem of architectural translation concerned with revealing the chapels 'secrets'.

Utilising a series of graphic studies I wish to tease out some version - a translation - of these 'secrets'. Remembering Zaknic's salient warning on translation, here I will be taking some very great liberties with Ronchamp. It is inevitable that many of these will be, if not outright wrongs, then definitely unstable positions. But maybe this is as it should be. The most powerful puzzle of Ronchamp is that we puzzle over it at all. That an extraordinarily 'odd ${ }^{10}$ piece of architecture should demand our continued interrogation is what marks it out as exceptional. In one of Ronchamp's first reviews James Stirling wrote with transparent suspicion of the dominant poetic expressiveness of the building, describing it in a Mannerist tradition as being a personal interpretation of rationalist architecture. ${ }^{11}$ Yet in a personal correspondence he went further into the anxiety presented by Ronchamp: "there is something about it (the idea in Corb's mind, I think) which I have failed to grasp. With considerable on the spot study I feel it might eventually communicate something of great importance - what?"12 The short answer to Stirling's rhetorical question is 'geometry'. The Modulor is the much longer answer but not, necessarily, the right one.

\section{Developing Argument}

To begin in on a contrary position, I will start by showing the extent to which mathematics latent in Ronchamp do not relate to the Modulor at all but instead turn to geometries of reflection, tangency and - as we might expect - the right angle. To set this stage I will give a detailed account of Ronchamp's geometric relationship to its surroundings. In making this case two linked themes are apparent. One is concerned with the way in which Ronchamp subsumed reference information from the site. The other details the degree to which Le Corbusier acted on the reverse principle and externalised the geometry of his chapel. In demonstrating this a case is made for an extent of creative invention in Le Corbusier's design for Ronchamp that is not concerned with the Modulor. The second part of this paper is then obliged to explain where we do find the Modulor. My proposition is that we find it in the most obvious of places but not in a lead role organisational as we might expect.

Le Corbusier's generally arrangement sketches for Ronchamp, especially the earliest examples, typically show a common organisation of architectural features. The most obvious of these is the extraordinary plan, with its highly distinctive relationship of curves readily traceable to the extant building. However there are a number of other features in the early project drawings that did not survive in any obvious way through the construction process. The disappearance of these elements, I suggest, represent the beginning of Ronchamp's secret geometry. I will address each in turn but to begin it is important to note that these elements fall into two distinction that can be simply differentiated as the 'external' and 'internal' spatial parameters. The latter category is very much concerned with the specific question of how Le Corbusier utilised the Modulor as a planimetric device. Here I wish to discuss a pair of factors that have acted about the plan of Ronchamp. This deals with two sets of conditions evident on the site plans.

\footnotetext{
${ }^{8}$ Evans, R. (1986). "Translations from Drawing to Building." AA Files(12): 3-18.

${ }^{9}$ Evans, R. (1995). The Projective Cast. Cambridge, Mass., The MIT Press. Page 315.

${ }^{10}$ Evans, R. (1995). The Projective Cast. Cambridge, Mass., The MIT Press. Page 315.

${ }^{11}$ Stirling, J. (1956). "Ronchamp: Le Corbusier's Chapel and the Crisis of Rationalism." The Architectural Review 119 (March 1956): 155-161.

12 James Stirling quotes in Girouard, M. (1998). Big Jim: The Life and Work of James Stirling. London, Chatto \& Windus. Page 83.
} 
The first of these concerns is the footprint of auxiliary buildings to the west of Ronchamp. The second addresses Le Corbusier's original campanile proposal. In both examples I will suggest that the Modulor is a minor organisational element at best, and that the principle geometric features in play have more in common with classical alignments and tangencies.

In making my case I will make each exegesis will be based on a series of diagrammes in which I overlay possible geometries onto Le Corbusier's drawings. The limits of reproduction, supposition, accuracy and assumption mean that this is inevitable a problematic approach. To any methodological criticism I think it important to say that I am not defending this approach as the 'correct' one. My point is more broadly concern with inviting into our understanding of Ronchamp a possible case for geometric certainties that has otherwise been overlooked.

\section{Case-study a) the significance of auxiliary buildings.}

In all of Le Corbusier's early site plans he records the footprints of auxiliary buildings to the immediate west of the chapel. It is possible in some photographs to discern the nearest of these as probably domestic, but today there is little left to suggest that these buildings existed let alone held any influence(1).

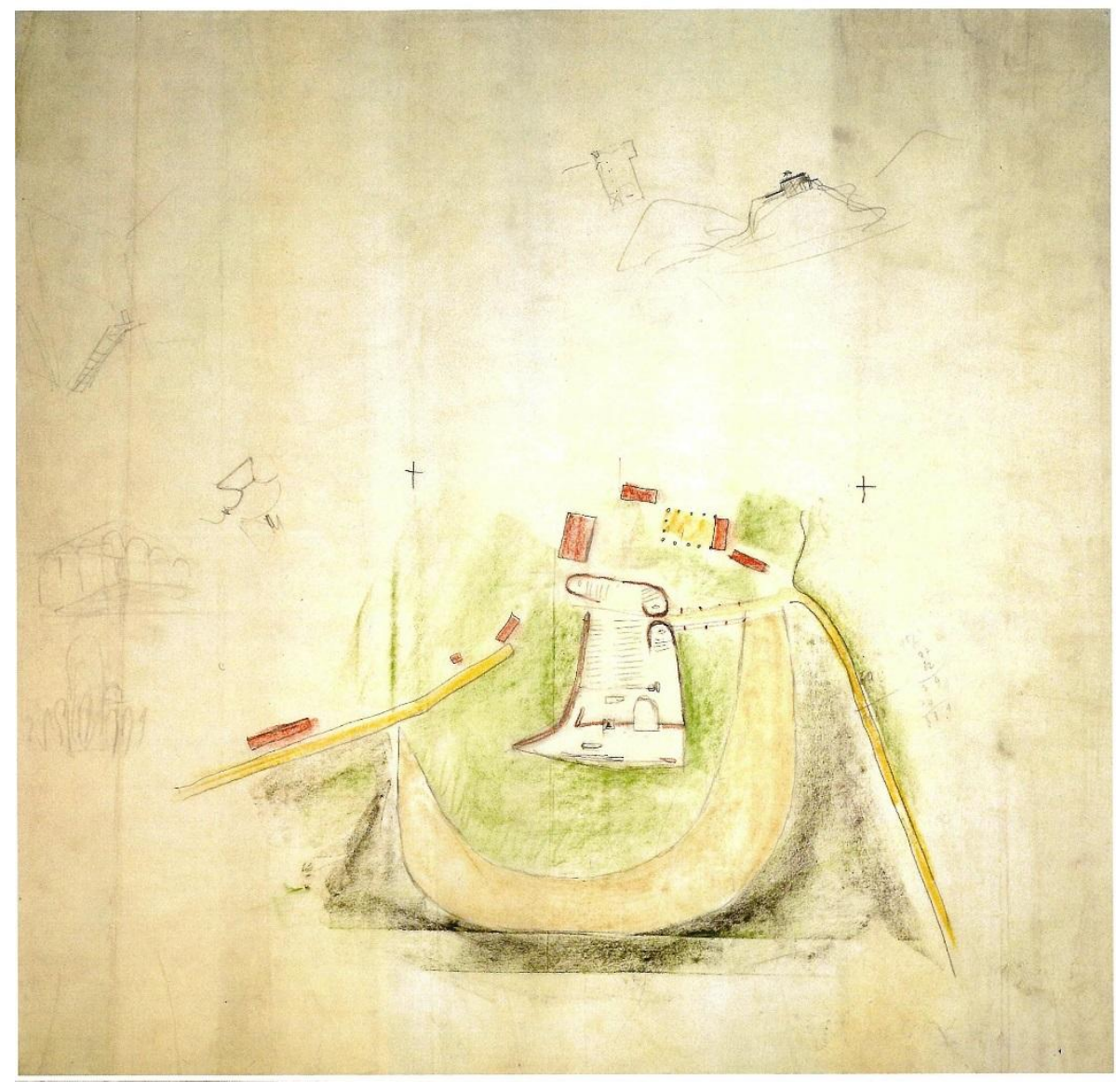

1. Ronchamp: Schematic Site Plan

There is a tentativeness towards the drawings of these buildings that they may have been somewhat less than complete when Le Corbusier's visited. The house to the south west that can be found in period photographs, is shaded in brown, adding to it an air of substantiality. But the patterns to the west are depicted in hesitant lines broken at regular intervals with columns or posts. In other places the post/column markers appear without the 
support of a wall. The curious suggestion in these drawings is that these might be temple-like buildings. The association I am making here is to the Acropolis, and I suggest that it is not accidental that Le Corbusier begins The Chapel at Ronchamp by describing his architectural epiphany of six weeks experiencing the 'soliloquies amongst the ruins' of the Acropolis. ${ }^{13}$ In this view Ronchamp is to the hill of Bourlémont as the Parthenon is to the Acropolis. In itself this is not a new position on Le Corbusier. Colin Rowe saw the same parallel in La Tourette. ${ }^{14}$ But in my view what is happening here is more than just analogy based on landscape or type but rather a serious attempt by Le Corbusier to apply geometric lessons to create a new Acropolis. To achieve this Le Corbusier the hill of Bourlémont as a field of existing points of coordination form which he extracted specific information (2).

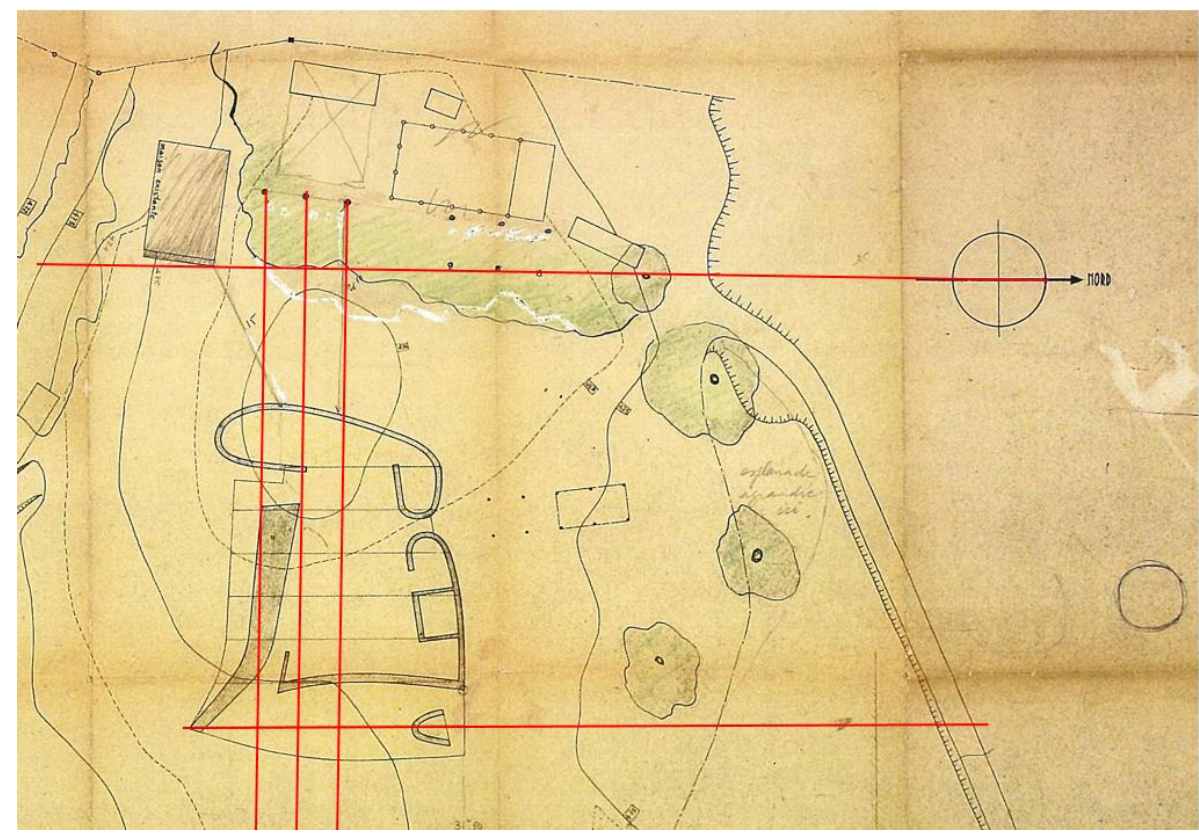

2. Ronchamp site plan (cropped), 13 December 1952, showing vertical alignments

Turning to the western outlines this influence begins with a grid set in place by three free columns depicted directly above Ronchamp. These can be found to drop vertically to cross perpendicular to an axis through the pilgrimage chapel. This produces a bipartite division to the plan that aligns with the footprint of the south wall. However the greater curiosity of this drawing is a second perpendicular crossing that simultaneously clips the east corner of the shaded dwelling, a fourth column, and a tree truck to arrive, most tellingly, on a direct alignment with the compass rose of the drawing. To appreciate that this is not just a convenience of draughting regulating lines are introduced that use the compass points as a datum (3).

\footnotetext{
${ }^{13}$ Le Corbusier (1957). The Chapel at Ronchamp. London, Architectural Press. Page 6.

${ }^{14}$ Rowe, C. (1982). The Mathematics of the Ideal Villa and Other Essays. Massachusetts, The MIT Press.
} 


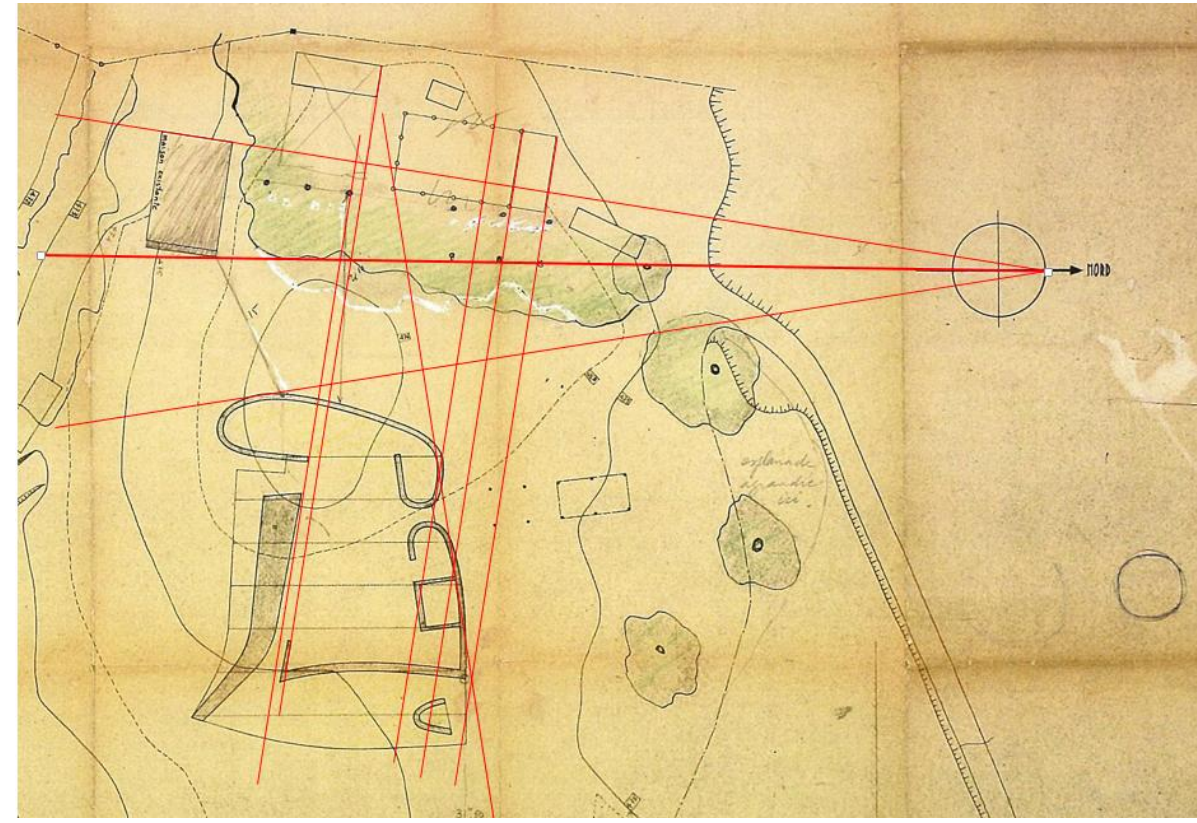

3. Ronchamp site plan (cropped), 13 December 1952, showing compass rose alignment

Demonstrated this way a second alignment to the shaded dwelling is realised, this time aligning directly to its west wall. The reflection vector that corresponds finds an equally pertinent tangency to the west most part of Ronchamp's west wall. However it is when perpendicular intersections are generated off the upper compass vector that a more compelling set of relationships occurs. In particular the temple-like figures produces alignments to the northeast corner of the chapel, but similarly spacings appear for the division between the southeast intersection (4).

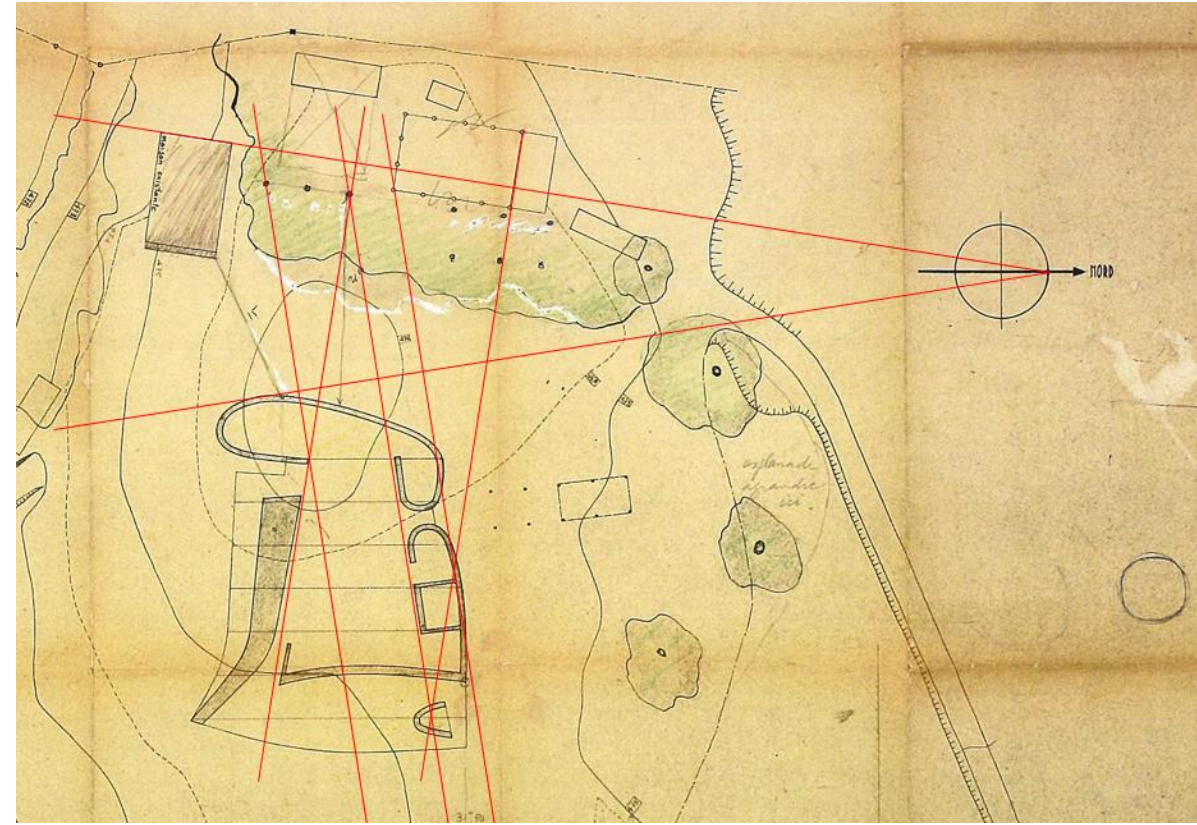

4. Ronchamp site plan (cropped), 13 December 1952, showing compass rose alignment

Introducing perpendicular crossings to the lower compass line produces similar alignments, this time to the intervals of the northern spaces and the nave. These alignments do not significantly account for the design of Ronchamp, but they do suggest the importance of external alignments as being necessary for the refinement of the design, and its placement in its physical context. But even more importantly, if we are to take as a serious 
intention the placement of the compass rose as a part of the geometric instrumentation of Ronchamp it demands of us a much richer understanding of how Le Corbusier used drawing as a methodological process. To show this I have a further variation on the western alignment for consideration (5).

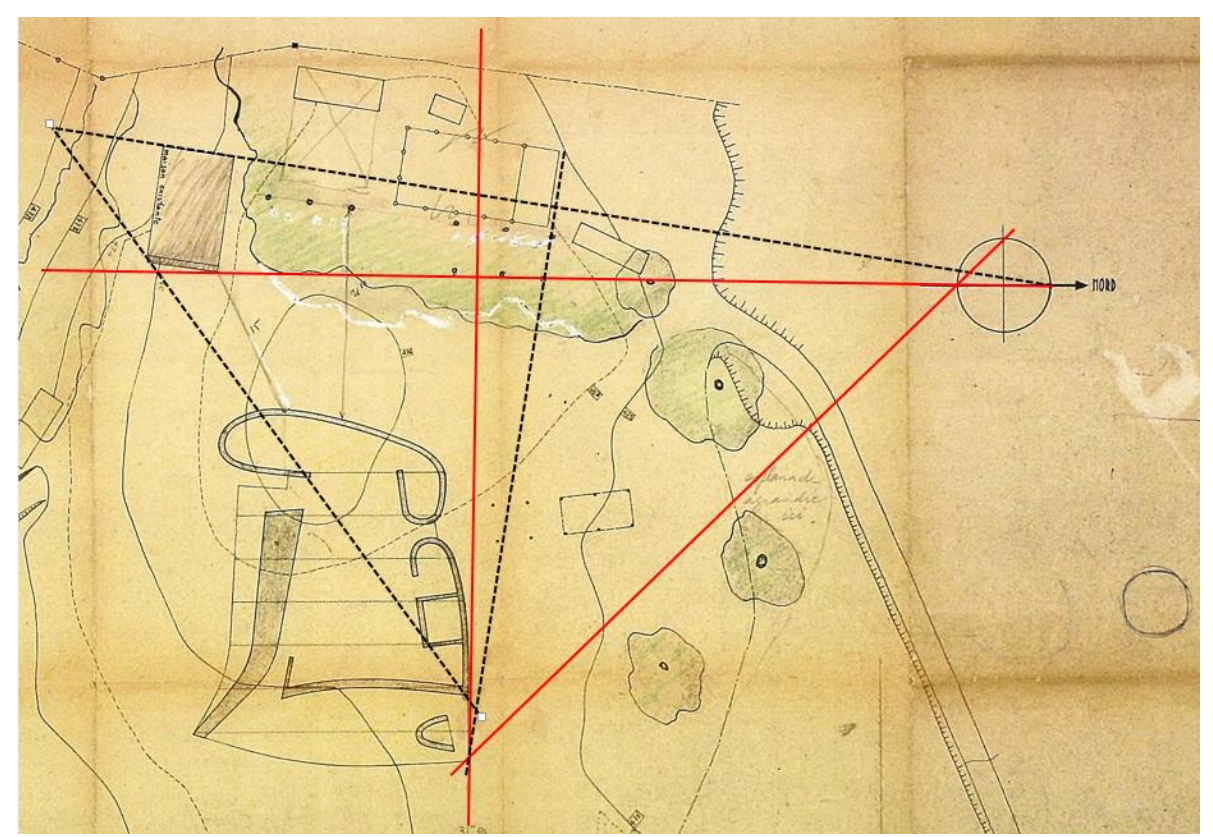

5. Ronchamp site plan (cropped), 13 December 1952, showing compass rose ancillary alignment

Taking the compass axis as a datum a right angle triangle can be generated off the south point that aligns with the northeast time of Ronchamp. In turn a second line can be drawn back from this point to produce a perpendicular intersect with the vector of the upper rose point. Now a second right angle triangle can be generated back via the southeast corner of the shaded dwelling to produce tangencies with three key points In Ronchamp's plan.

At this point it is worth considering that these studies might be little more than the manipulative products of a fertile imagination coupled to the extraordinarily rich possibilities offered by Le Corbusier. They are, at best, examples of circumstantial evidence that is not easily proved. If there is a 'proof' here it one revealed by the insistent occurrence of geometric alignments rather than any one example. To that end I wish to examine the artefacts to the south to suggest that LE Corbusier also drew geometries out of Ronchamp to make decision concerning the dormitory accommodation (6). 


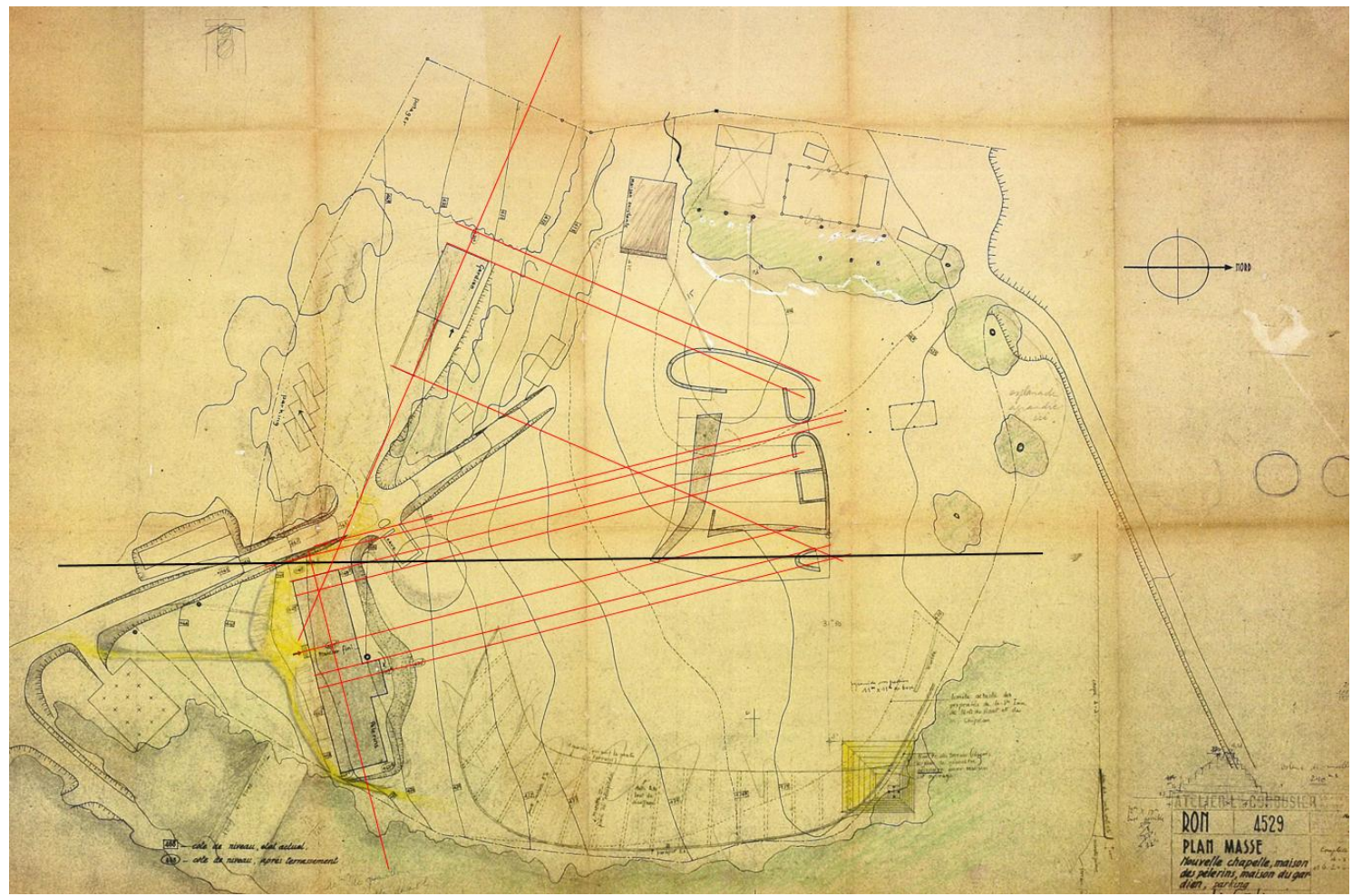

6. Ronchamp site plan (cropped), 13 December 1952, alignment to dormitory

In the first of these I have identified the centreline of the dormitory block, from which perpendicular projections have been taken form points of demonstrable significance (walls, changes in direction, elements highlighted on the drawing, and so on). In this model Ronchamp provides the frame of geometric reference from which the dormitory placement and dimensions can be determined. Similarly the extent of the western accommodation block can be determined Working backwards perpendicular alignments can once more be found to the major intervals in the chapel, and with the introduction of an axial datum through the pilgrimage chapel a reflection line is located.

I would like to turn one final example of ancillary alignments. Despite its prominence the monument de la Paix receives remarkable little attention from scholars. One reason for this is that the simplicity of the regular stepped pyramidal form is so at odds with the complex curves of the chapel. But if anything we should look at the monument even more closely for the way in which its design and construction presents a versions of Le Corbusier's preference for dialectical elements. Against the obviousness of the monument early plans show, to the south of the dormitory, provision for a formal grove (7). 


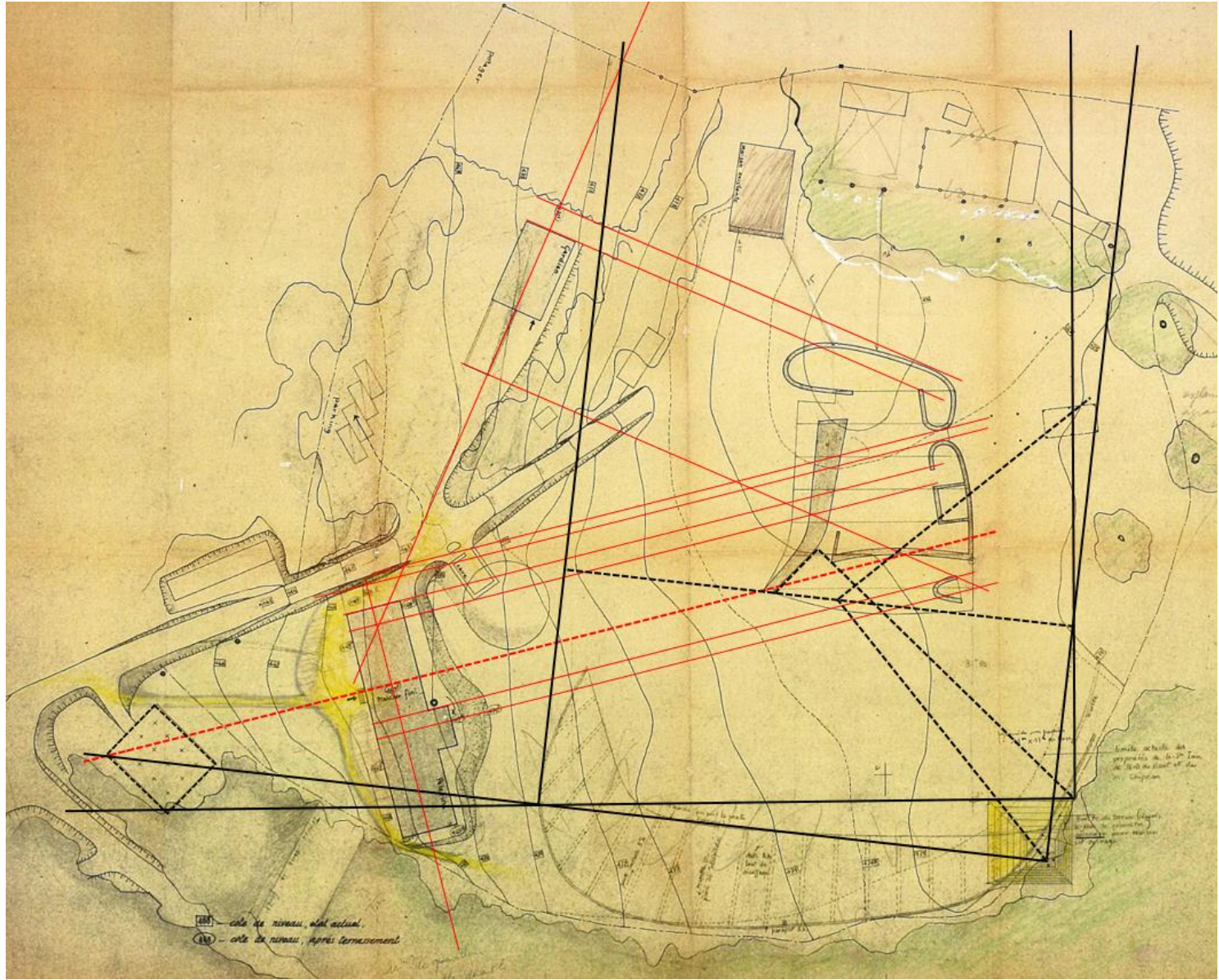

7. Ronchamp site plan (cropped), 13 December 1952, alignment to dormitory

Together these two elements take their datum points from the chapels plan. A parallel line taken from the northwest corner of the monument provides a tangency for the grove, and when taken westwards intersects with the enclosed component of the proposed campanile. At the same time a diagonal bisection of the grove aligns to the peak of the monument, and a perpendicular extraction of this point intersects with the first posts of the original campanile. The significance of this can be found where the two skewed right angles intersect on the vertical axis. By taking a perpendicular projections off at this point a secondary axis is found that passes though the southeast tip of the chapel. Finally, by splitting both right angles against the southeast tip alignments back to the campanile and south wall vector can be found.

In discussing the role of ancillary elements to the geometry of Ronchamp two quite different principles are apparent. In the first I have suggested that latent architectural information to the north of Ronchamp was used as an early generator of reference points. However, once the plan of Ronchamp was resolved Le Corbusier then found point of alignment and tangency which could be projected out into the surrounding landscape to locate additional architectural elements. In the next part I will look more closely at how the original campanile proposal had a more intimate role.

\section{Case-study b) the significance of the original campanile.}

From the his earliest sketches for Ronchamp Le Corbusier had proposed a simple scaffold-like campanile organised on an axial alignment with the northern entrance. That this was a serious part of Ronchamp's conception and development cannot be doubted and it appears in all the developmental workings leading right to 
the formal scheme. In both the elevation and the model photo-montage reproduced in his oeuvre complete the campanile is a visually dominant element in the composition (8).

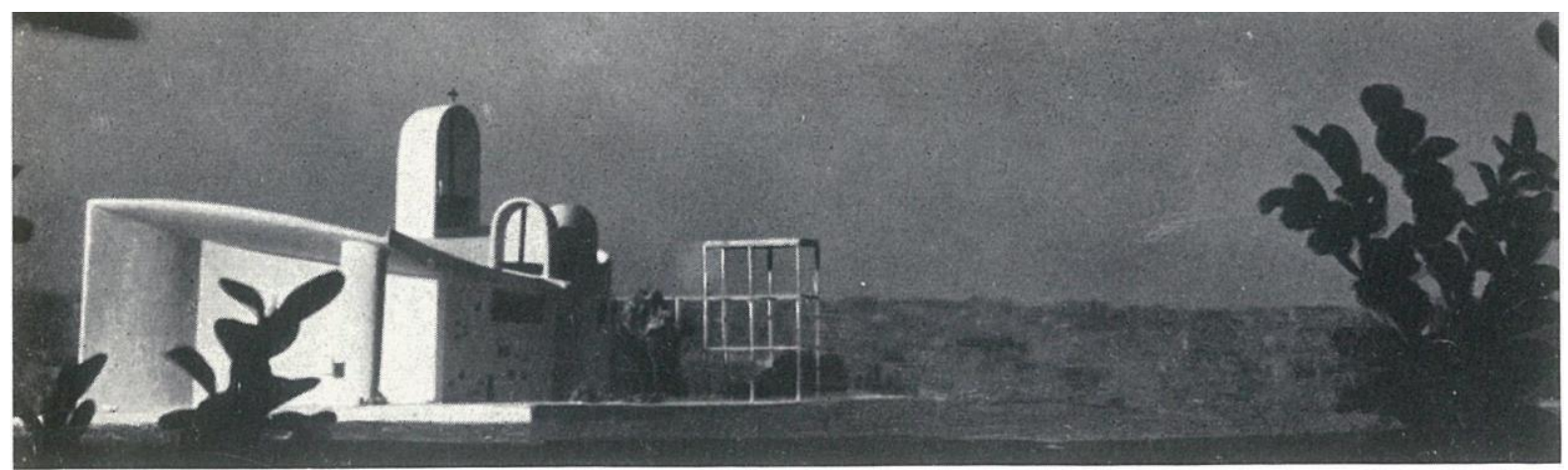

8. Maquette de la chapelle

To speculate on the meaningfulness that this might hold I suggest that the purpose of the campanile's dominance is as a parallel symbolic element to the three towers. I broadly concur with interpretations that find in Ronchamp's three towering light-wells associations to the female figures of greatest influence in Le Corbusier's life. ${ }^{15}$ Against this triadic "cult of Mary ${ }^{, 16}$ the campanile is, I suggest, a biographical manifestation of Le Corbsuier's masculinity. This substantially accounts for the opposition of compositional elements: the solid curves of the towers against the open post and beams of the campanile. It could also be read as a very literal manifestation of Le Corbusier's meant when he mentions the 'phenomonon of visual acoustics' of Ronchamp ${ }^{17}$. Evans and Scully ${ }^{18}$, amongst others, have tended to interpret this as spatial metaphor, but had the campanile been constructed as Le Corbusier first intended he would have achieved something far more directly acoustic. The proximity and placement of the bells so close to Ronchamp would have created unique acoustic properties as the sound was reflected around the curved forms. The two northern towers, directly in line with the campanile, would have 'funnelled' the sound across Ronchamp's roof. By contrast the larger southern tower, facing as it does toward the north, would have become an acoustic trap, directing any sound it received down into the altar space beneath in a most direct version of the acoustic detection apparatus he reproduced in his 1935 publication, Aircraft ${ }^{19}$

If the campanile was such an important biographical and acoustic component to Ronchamp then losing it from the final outcome might look like a failure of sorts of Le Corbusier to realise a complete scheme? That so little attention has been given to the first campanile suggests that this is not the case. Indeed, viewing it now the gridded scaffold form is a glaring intrusion on the curves of the chapel. However I don't think we should accept that the influence of the campanile is negligible because its physical presence is missing. To show what this means we need to examine the geometric influence of the campanile. The drawing numbered RON. 4457 is particular helpful for this analysis as it is one of the few in which we find an organisational grid imposed on Ronchamp, with an axis through the chapel made clear (9).

\footnotetext{
${ }^{15}$ Samuel, F. (2004). Le Corbusier: Architect and Feminist. Great Britain, Willey-Academy.

${ }^{16}$ Flora, S. and I. Linder-Gaillard (2013). Sacred Concrete: The Churches of Le Corbusier. Basel, Birkhäuser. Page 108.

${ }^{17}$ Le Corbusier (1957). The Chapel at Ronchamp. London, Architectural Press. Page 89.

${ }^{18}$ Evans, R. (1995). The Projective Cast. Cambridge, Mass., The MIT Press. Scully Scully, V. (1961). Modern Architecture. New York, Braziller.

${ }^{19}$ Le Corbusier (1988). Aircraft. New York, Universe Books.
} 


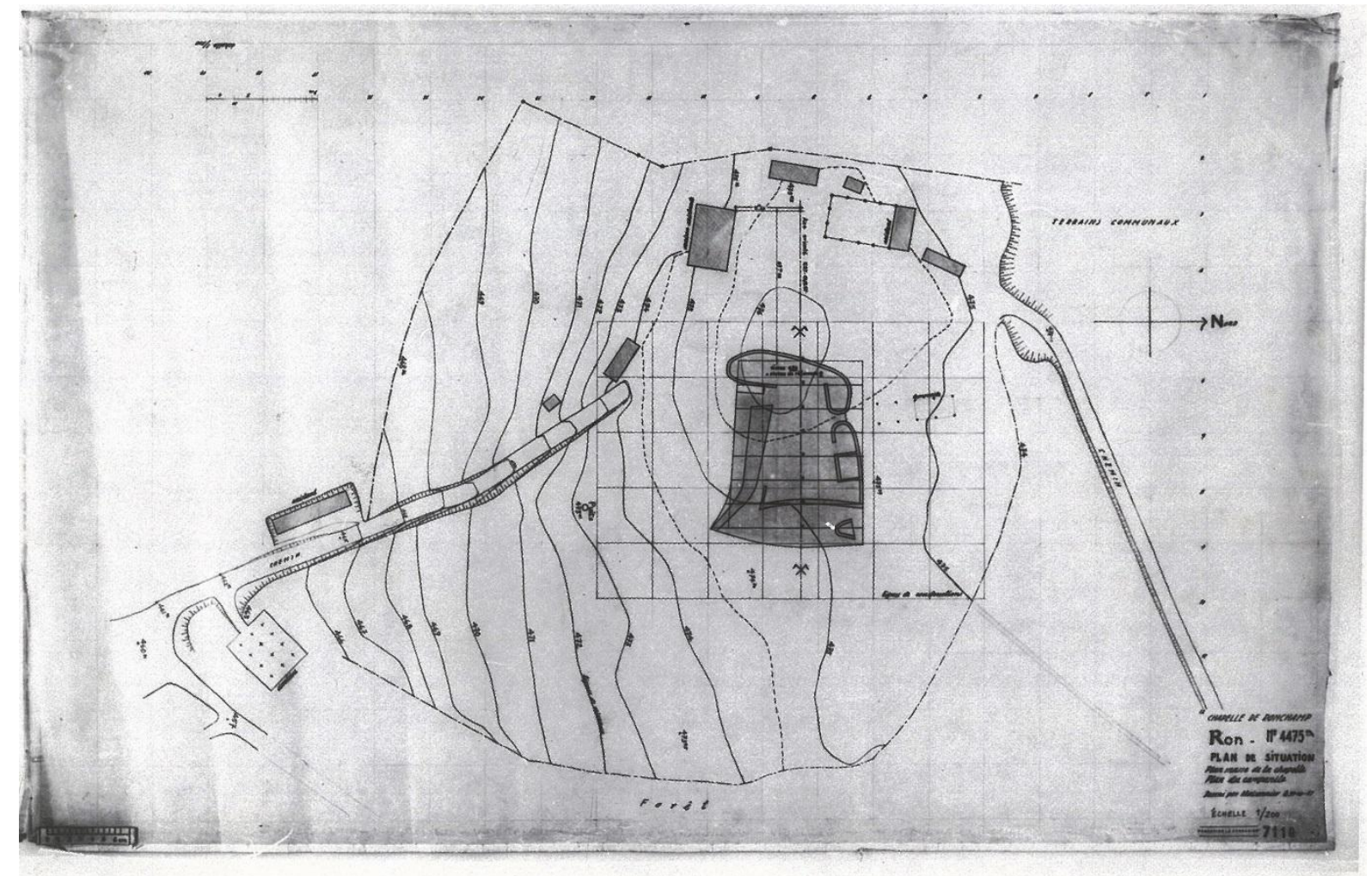

9. Ronchamp Plan de situation, 1952

The first observation to be made about this drawing is that we find here an alignment between the grid and the compass rose, suggesting once more the significance of the compass as a geometric reference point. The second observation concerns the divergence between the overlaid gird and the axis of the campanile. That said the preliminary alignments are immediately apparent. Using the grid/compass axis as the horizontal datum, 45 degree vectors can be taken off the centreline icons on the vertical axis to coincide with both the obvious overgrid of the plan and the campanile grid. Recognising that these two grids are not aligned adds significance to this configuration (10). 


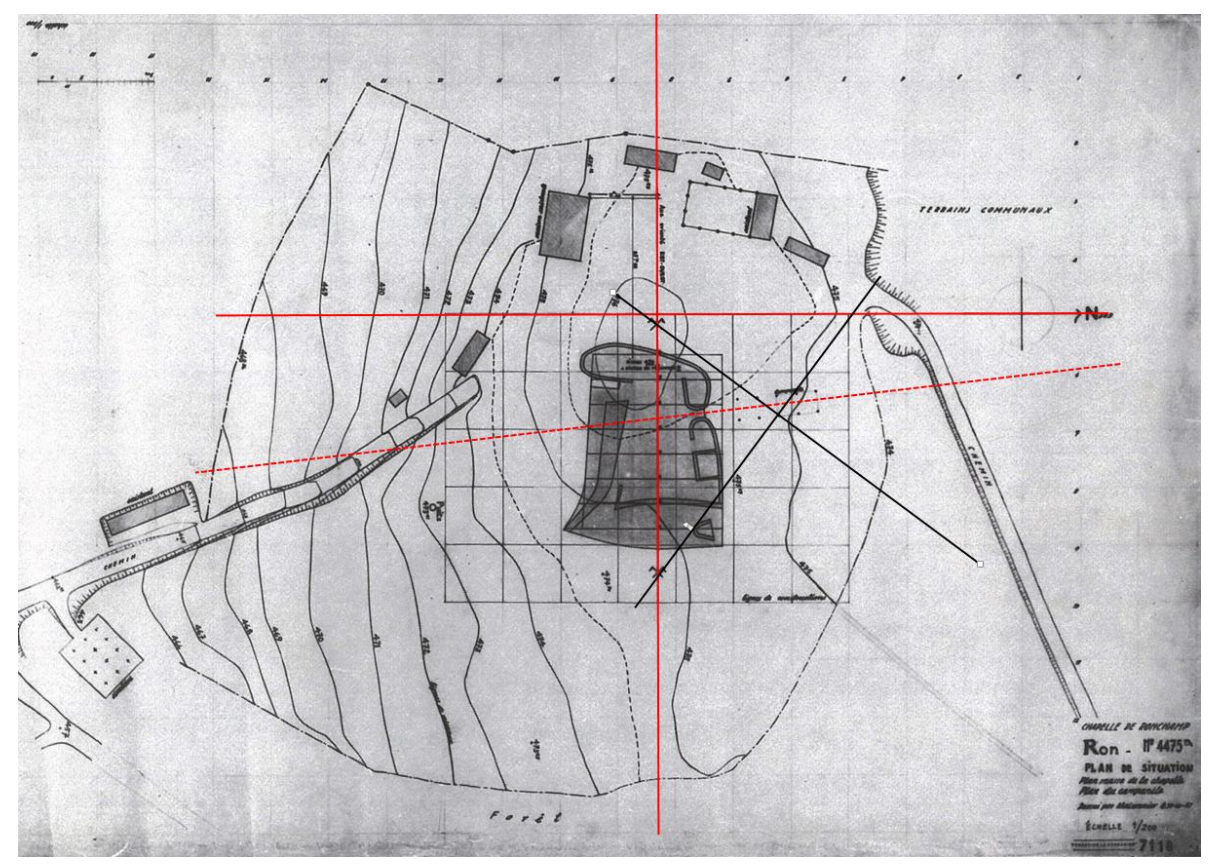

10. Ronchamp with campanile alignment

In the next move I will return to the geometry of the compass point to find a vector between the tip of the compass and the point where the central axis finds the bottom of the plan grid. In turn this line if reflected across the horizontal datum of the grid/compass to find a mirroring intersection at the top of the central axis. Reflecting both these lines across the vertical axis then locates two important points. The first is a tangency with the southeast corner of Ronchamp. The second, tellingly, is an aligned intersection between the axis of the campanile and the left-hand margin of the plan grid (11).

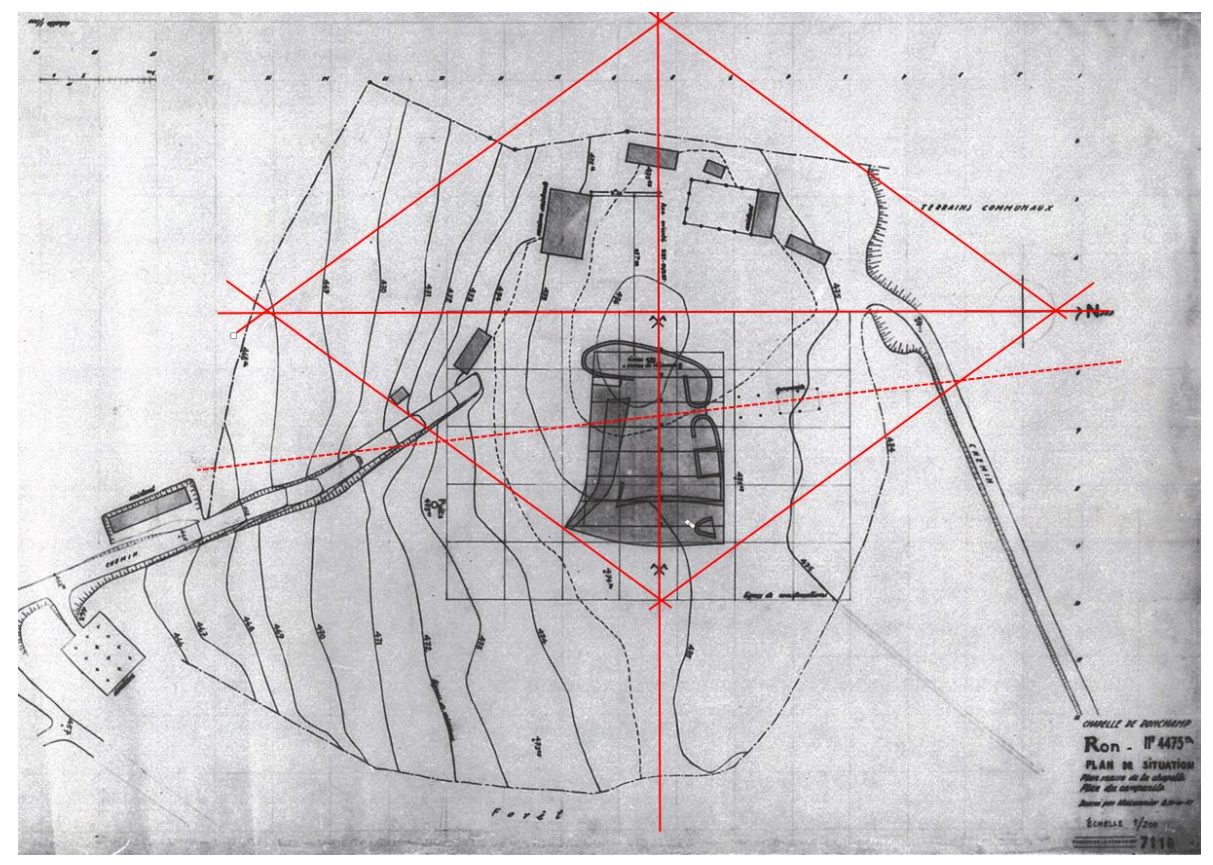

11. Ronchamp with campanile triangulation

These alignments become more convincing when perpendicular versions of the campanile axis are introduced. The most important of these takes the upper point of intersection and find a centreline through the northern altars and entrance. When reflected to the other side of the axis this vector runs parallel to the external south wall. In a 
third move, if the campanile axis line is reflected across the grid/compass axis an alignment occurs with the western structures (12).

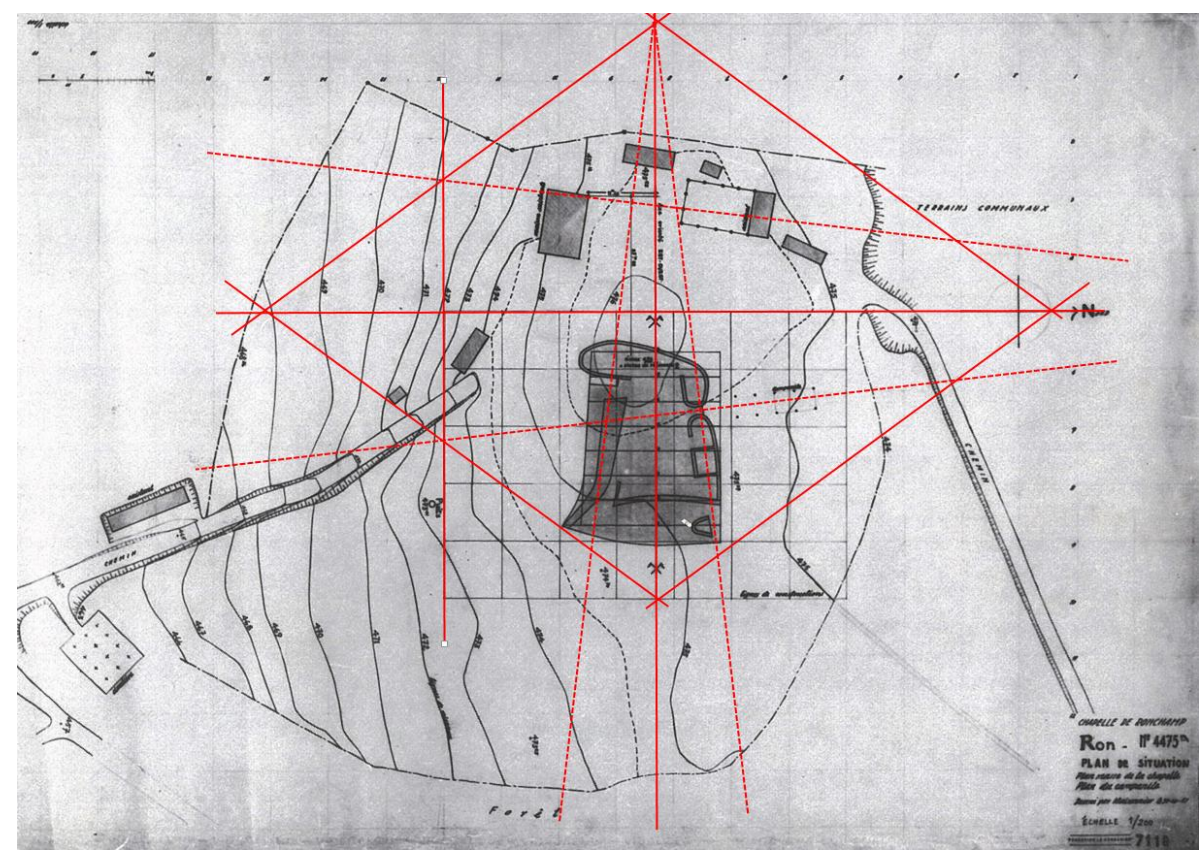

12. Ronchamp with campanile triangulation

In the next development I have added a crossing vector derived from a campanile diagonal that, by reflecting through the vertical axis, creates a chevron and the beginning of a pentagram. Once more inverting this form across the grid/compass line produces alignments with the western ancillary forms (13).

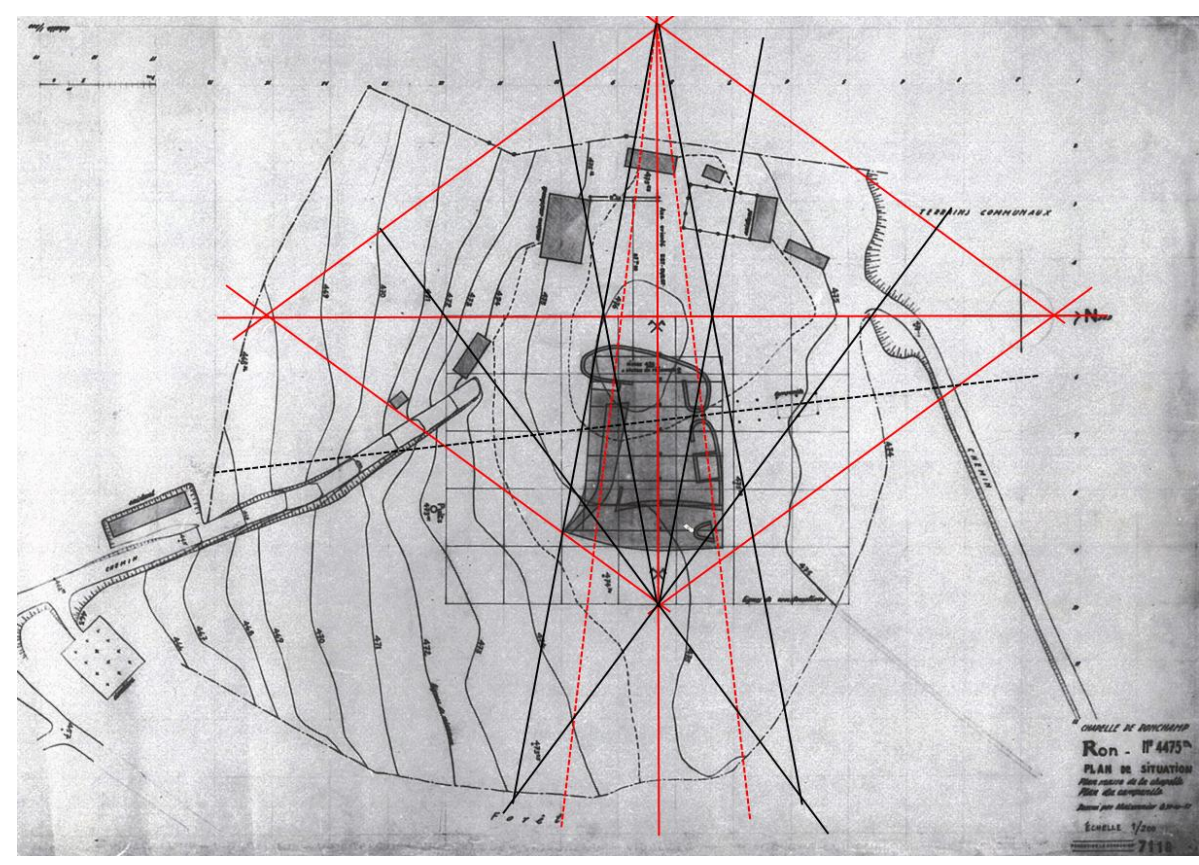

13. Ronchamp with campanile triangulation

It should be of interest that the asymmetry of Ronchamp should start to fall into the kind of symmetrical figuration that underpins the organisational structure of his paintings, and especially his enamel on the door of 
Ronchamp. ${ }^{20}$ However the real impact of the campanile can be found if a more universal grid generated by it is expanded over the entire plan (14).

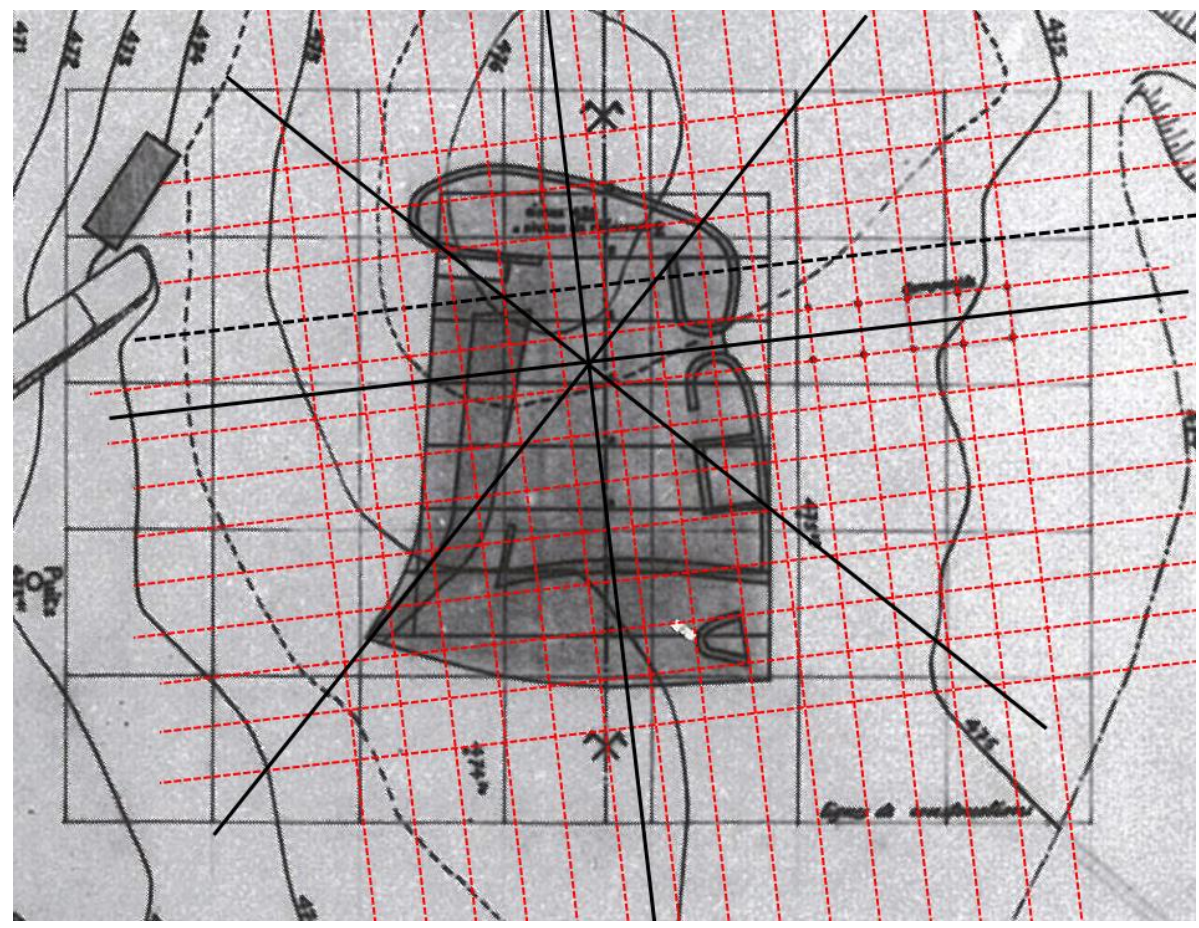

14. Ronchamp with campanile grid (detail)

Alignments here are not dramatic but they are significant. Of particular note is the fact that the eastern pulpit occupies the proportions of the campanile perfectly. Returning to the centre axis of the campanile, the plan can be dissected into quadrants which produce tangencies with many key components including the south entrance, southeast corner, secondary chapel limits and main altar.

\section{Conclusion}

Le Corbusier first visited the site for what would become the Chapel of Notre-Dame-du-Haut at Ronchamp on June $4^{\text {th }}, 1950$. In the company of Canon Ledeur he climbed the processional path of the hill Bourlémont to the remains of a pilgrimage chapel destroyed in the recent war. As Le Corbusier recalls it, at that time he carefully drew a response to the site based upon the four horizons and a resultant volume which "architecturally triggered the acoustic response - acoustics in the realm of forms" ${ }^{\text {"21 }}$. It is now a part of Ronchamp's enigmatic legend that the graphic documentary of its 'spontaneous birth',22 are long gone, 'misplaced or lost', as Le Corbusier put it ${ }^{23}$. But if we are left with some question of Ronchamp's genesis Le Corbusier seems as surprised of its outcome as us. Revisiting Ronchamp several years after its completion he expressed this creative uncertainty when he asked, "But where did I get all that?"24. By 'all that' we should not think that Le Corbusier did not have a singular sense of why or how Ronchamp came to be. Indeed, I plan to show here that the actuality of Ronchamp was quite the product of singular certainty. That we could take from Le Corbusier's comment is a more universal truth of

${ }^{20}$ Reichlin, B. (1997). Jeanneret-Le Corbusier, Painter-Architect. Architecture and Cubism. E. Blau and N. J. Troy. Cambridge, Massachusetts, The MIT Press: 195-218.

${ }^{21}$ Le Corbusier, Textes et dessins pour Ronchamp, unpaginated.

${ }^{22}$ Le Corbusier, Textes et dessins pour Ronchamp, unpaginated.

${ }^{23}$ Le Corbusier, Textes et dessins pour Ronchamp, unpaginated.

${ }^{24}$ Pauly the chapel of ronchamp in brooks ed. Page xiv. 
architectural design in which a separation can be made between the 'that' of a building (a complex entity of myriad decisions) and the 'this' of a design procedure that directs the buildings architecture. When facing Ronchamp we can, in common with Le Corbusier, marvel at the 'that-ness' of it, but we should be in no doubt that he knew exactly what he did to get from 'this' to 'that'.

Any vagueness Le Corbusier might imply about the creative derivation of Ronchamp is missing where he hints at the execution of the design. In Texts and Sketches for Ronchamp he writes of ". . the clarity of the relations, everything being based on the faultless mathematics of the combinations." ${ }^{25}$ Guessing the origin of Ronchamp has become an opening gambit for Corbusian scholars. For James Stirling it presented itself like a large thumb emerging form the hill ${ }^{26}$. Charles Jenck's found a cornette, clasped hands and a duck, and more. ${ }^{27}$ There are many other suggestions but the 'truth' (if we can ever use such a word with Le Corbusier) is probably far too inclusive to identify one reading as correct. However, for the sake of the argument I am presenting here I think it useful to look to the most obvious and familiar comparison as a guide. That is, that Ronchamp was principally conceived with a boat in mind. The usefulness in this bias is that it paces its conceptual emphasis an 'outside' element: the ship-shape of the western outdoor pilgrimage chapel. I think we can be even more specific about this source. In his work on Le Corbusier's 'secret photography' Tim Benton reproduces a series of photographs captured by the architect in September, 1936. In these images of the small fishing boats of Arcachon Bay, Le Piquey, it is impossible not to see in their rising bows a prototype of Ronchamp (15). But more than that, each boat is numbered, and each number is prefaced with the boats port of origin: 'ARC'. We should think of Ronchamp as more than boat-like, but as an actual boat. Grounded on the crest of Bourlémont it is simultaneously evokes Noah's Ark, the architecture of the Acropolis, and the arcs of tangency present through geometry. The sharp relevance of this is found in the different axis of movement between buildings and boats where the latter adds to the stable Cartesian coordinates of $\mathrm{x}, \mathrm{y}$ and $\mathrm{z}$ the dynamic attributes of roll, yaw and pitch. The Modulor, it should be apparent, operates best when applied to predictable surfaces. Ronchamp, on the other hand, is an extraordinary exploration in form where the traditional stabilities of top/bottom, near/far and left/right have been superseded by dynamic relationships. As Le Corbusier teased in a caption from The chapel at Ronchamp, "try to look at the picture upside-down or sideways. You will discover the game." 28

\footnotetext{
${ }^{25}$ Texts and Sketches for Ronchamp, unpaginated.

${ }^{26}$ Stirling, J. (1956). "Ronchamp: Le Corbusier's Chapel and the Crisis of Rationalism." The Architectural Review 119 (March 1956): 155-161.

${ }^{27}$ Jencks, C. (2000). Le Corbusier: And the Continual Revolution in Architecture. New York, The Monacelli Press.

${ }^{28}$ Le Corbusier (1957). The Chapel at Ronchamp. London, Architectural Press. Page 46.
} 


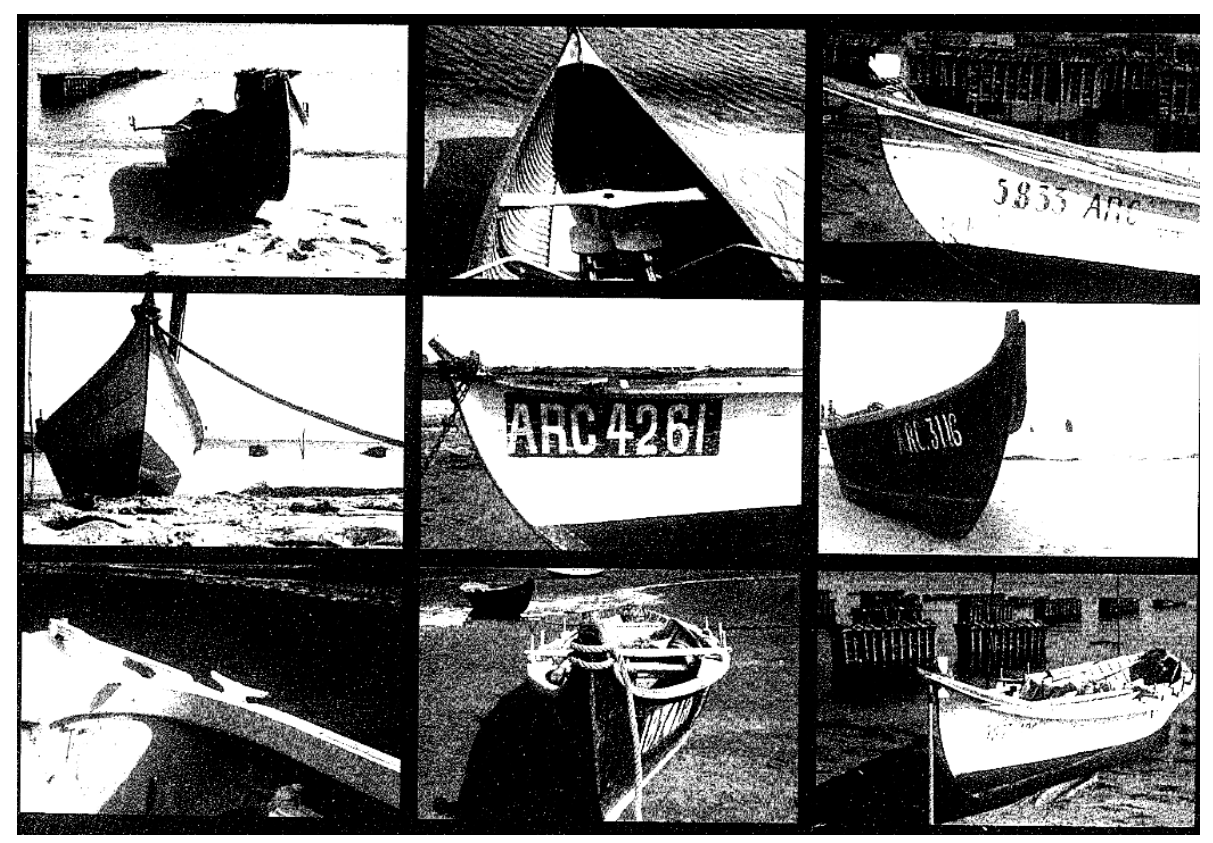

15. Pinasses, Le Piquey, Bassin d'Arcachon, September 1936

\section{Figures}

1: Ronchamp, schematic site plan Le Corbusier Le Grand page 559. OFLC-ADAGP

2, 3, 4, 5, 6, 7: Site plan of Notre-Dame-du-Haut and associated buildings. 13 December 1952. FLC Ron. 4529. CFLC-ADAGP

8: Marquette de la chapelle Le Corbusier The Complete Works Vol. V, page 72. OFLC-ADAGP

9, 10, 11, 12, 13,14: Plan de situation, plan de la chapelle et du campanille FLC 7.118. OFLC-ADAGP

15: Pinasse FLC Sequence 31346, 31351, 32384, 32389, 16455, 31112, 31408, 31404, 32385. OFLC-ADAGP

\section{Bibliography}

Evans, R. The Projective Cast. Cambridge, Mass.: The MIT Press, 1995

Evans, R. "Translations from Drawing to Building” AA Files (12), 1986: 3-18.

Girouard, M. Big Jim: The Life and Work of James Stirling. London: Chatto \& Windus, 1998

Jencks, C. Le Corbusier: And the Continual Revolution in Architecture. New York: The Monacelli Press, 2000

Jencks, C. Le Corbusier and the Tragic View of Architecture. Middlesex, England: Penguin Books, 1987

Le Corbusier. Aircraft. New York: Universe Books, 1988

Le Corbusier. The Final Testament of Pere Corbu: A Translation and Interpretation of Mise au point by Ivan Zaknic. New Haven and London: Yale University Press, 1995

Le Corbusier Modulor 21955 (Let the User Speak Next) Continuation of 'The Modulor' 1948. Cambridge, Massachusetts, and London England: The M.I.T. Press, 1958

Le Corbusier. The Chapel at Ronchamp. London: Architectural Press, 1957

Le Corbusier, Textes et dessins pour Ronchamp, Paris: Éditions Forces vives Impr. I.L.C., 1965.

Pauly, D. "Chapelle Notre-Dame-du-Haut" in The Le Corbusier Archive, vol. 20. Ed. H. A. Brooks, Garland Publishing and Fondation Le Corbusier: Paris, 1983 
Pauly, D. “The Chapel of Ronchamp” Architectural Design 55 (7/8), 1985: 30-37.

Reichlin, B. "Jeanneret-Le Corbusier, Painter-Architect" Architecture and Cubism. E. Blau and N. J. Troy. Cambridge, Massachusetts: The MIT Press, 1997.

Rowe, C. The Mathematics of the Ideal Villa and Other Essays. Massachusetts: The MIT Press, 1982

Samuel, F. Le Corbusier: Architect and Feminist. Great Britain: Willey-Academy, 2004

Samuel, F. and I. Linder-Gaillard Sacred Concrete: The Churches of Le Corbusier. Basel: Birkhäuser, 2013

Scully, V. Modern Architecture. New York, Braziller, 1961

Stirling, J. "Ronchamp: Le Corbusier's Chapel and the Crisis of Rationalism" The Architectural Review 119, 1956 